\title{
Activation Energy for Water Diffusion across the Toad Bladder: Evidence against the Pore Enlargement Hypothesis
}

\author{
Richard M. Hays, Nicholas Franki, and Roy Soberman \\ From the Department of Medicine and Unit for Research in Aging, \\ Albert Einstein College of Medicine, New York 10461
}

\begin{abstract}
A в S T R A C T The activation energy $\left(E_{\mathbf{A}}\right)$ for the diffusion of water across the epithelial cell layer of the toad bladder was determined in the absence and presence of vasopressin. An experimental approach was employed which minimized the effects of unstirred layers and the thick supporting layer of the bladder on the measurement of water diffusion. $E_{\Delta}$ in the absence of vasopressin was $11.7 \pm 1.4 \mathrm{kcal} \cdot \mathrm{mole}^{-1}$; after vasopressin it was 10.6 $\pm 1.1 \mathrm{kcal} \cdot \mathrm{mole}^{-1}$. The difference between the two values was not significant. The results are consistent with an increase in the number rather than the size of aqueous channels in the cell membrane, a finding which differs from the generally held view that the hormone increases the radius of pores in the membrane.
\end{abstract}

\section{INTRODUCTION}

Vasopressin is believed to enlarge aqueous channels in the cell membrane, permitting an increase in bulk flow of water across the epithelial cell $(1,2)$. Experimental support for this hypothesis (the "pore enlargement hypothesis") was obtained in studies of the activation energy for the diffusion of tritiated water across the toad bladder (3); activation energy was high (9.8 $\left.\mathrm{kcal} \cdot \mathrm{mole}^{-1}\right)$ in the absence of vasopressin, but dropped to $4.1 \mathrm{kcal} \cdot \mathrm{mole}^{-1}$ in the presence of the hormone. Since this latter value was close to the activation energy for the diffusion of water in water, the experiment suggested that vasopressin did indeed enlarge aqueous channels in the membrane, providing an environment for the diffusing molecules close to that of bulk water.

The present studies have as their starting point the observation that unstirred layers of water in apposition to the bladder, and the thick tissue layer supporting the

This work was presented in part at The Eastern Section Meeting of The American Federation for Clinical Research, New York, 12 December 1970.

Dr. Hays is a Career Scientist, Health Research Council of the City of New York.

Received for publication 15 December 1970. epithelial cells, provide significant resistance to the diffusion of water after vasopressin (4). When the contribution of these extraneous layers is taken into account, the rate of diffusion of water proves to be far higher than has been recognized. We have therefore restudied the effect of temperature on the role of diffusion of water across the toad bladder, using an experimental approach in which the resistance of the unstirred layers and supporting layer is minimized, and in which the activation energy for the diffusion of water across the epithelial cell layer alone can be estimated. In contrast with the earlier findings, activation energy is high both in the presence and absence of vasopressin. The results indicate that the hormone may increase the number rather than the size of aqueous channels in the cell membrane.

\section{METHODS}

Paired hemibladders from Dominican Republic toads ( $B u f o$ marinus, National Reagents Inc., Bridgeport, Conn.) were mounted in chambers equipped with motor-driven paddles (4), with stirring speed set at $580 \mathrm{rpm}$. One chamber was run at room temperature; the chamber with the paired halfbladder was run in a cold room at $7-8^{\circ} \mathrm{C}$. Phosphate-buffered amphibian Ringer's solution ( $\mathrm{pH} 7.4,230 \mathrm{mOsm} / \mathrm{kg}$ ) bathed both sides of the bladders. The temperature of the Ringer's solution was monitored during the experiment, and did not change more than $0.5^{\circ} \mathrm{C}$. The permeability coefficient $\left(\mathrm{K}_{\text {trans }}\right)^{1}$ for tritiated water (THO, New England Nuclear Corp., Boston, Mass.) was determined for a $30 \mathrm{~min}$ period for both bladders, in the presence or absence of vasopressin $(80 \mathrm{mU} / \mathrm{ml})$. The chambers were then emptied of Ringer's solution (with the bladder still in place) and refilled with calcium-free Ringer's solution for $30 \mathrm{sec}$. This was repeated twice, and had the effect of loosening the bladder epithelial cells (5). The chambers were then carefully separated with the bladder still covering one chamber half, a glass microscope slide was placed under the bladder, and the epithelial cells were scraped off the bladder with a glass coverslip. The chambers were then reassembled, filled with calcium containing Ringer's solution, and the $\mathrm{K}_{\mathrm{trans}} \mathrm{THO}$

${ }^{1}$ Abbreviations used in this paper: $\mathrm{E}_{\mathrm{A}}$, activation energy; $\mathrm{K}_{\mathrm{trans}}$, permeability coefficient. 
TABLE I

Activation Energy for THO Diffusion across Intact Bladder (Stirring Speed $580 \mathrm{rpm}$ )

\begin{tabular}{|c|c|c|c|}
\hline \multirow[b]{2}{*}{ Vasopressin } & \multicolumn{2}{|c|}{$\mathrm{K}_{\text {trans }} \mathrm{THO}$} & \multirow[b]{2}{*}{$\mathbf{E}_{\boldsymbol{A}}$} \\
\hline & Cold* & Room temp. & \\
\hline & \multicolumn{2}{|c|}{$\mathrm{cm} \cdot \mathrm{sec}^{-1} \times 10^{7}$} & kcal $\cdot$ mole $^{-1}$ \\
\hline Absent (10) $\ddagger$ & $436 \pm 49(\mathrm{SE})$ & $1107 \pm 60$ & $10.7 \pm 1.2$ \\
\hline Present (7) & $2140 \pm 132$ & $4610 \pm 361$ & $8.5 \pm 0.7$ \\
\hline
\end{tabular}

* For each experiment, the precise cold room and room temperatures were used in calculating $E_{\mathrm{A}}$. For all experiments, temperature range for the cold room was $6-8^{\circ} \mathrm{C}$, for room temperature $21-25^{\circ} \mathrm{C}$.

$\ddagger$ Numbers in parentheses indicate number of experiments.

determined across the supporting layer of the bladder for a second 30 min period, at room temperature and in the cold. In experiments in which vasopressin had been used initially for the intact bladder, it was placed in the serosal medium bathing the supporting layer. The experiments provided values for $K_{\text {trans }}$ THO for intact bladders, and for the supporting layers, at room temperature and in the cold. Using the expression for the resistance of barriers in series $(6,7)$,

$$
\begin{aligned}
& \frac{1}{\mathrm{~K}_{\text {trans }} \text { intact }}=\frac{1}{\mathrm{~K}_{\text {trans }} \text { epithelial layer }} \\
&+\frac{1}{\mathrm{~K}_{\text {trans }} \text { supporting layer }},
\end{aligned}
$$

it was possible to solve for $K_{\text {trans }}$ THO across the epithelial layer alone at the two temperatures. The activation energy $\left(E_{A}\right)$ for water diffusion in the presence and absence of vasopressin was then calculated, using the Arrhenius equation.

\section{RESULTS}

$E_{\mathbf{A}}$ of intact bladders. $\mathrm{E}_{\mathbf{A}}$ in the absence and presence of vasopressin was $10.7 \pm 1.2$ and $8.5 \pm 0.7 \mathrm{kcal} \cdot \mathrm{mole}^{-1}$, respectively (Table $I$ ). $E_{A}$ in the absence of vasopressin differed little from that obtained in unstirred chambers (3) ; E $E_{A}$ after vasopressin, however, was considerably higher than the earlier value of $4.1 \mathrm{kcal} \cdot \mathrm{mole}^{-1}$. To confirm the fact that unstirred layers had an important effect on $E_{\Delta}$ after vasopressin, $E_{\Delta}$ was determined in a series of experiments in which stirring speed varied from 60 to $800 \mathrm{rpm}$ (Table II). $E_{\mathbf{A}}$ increased progres-
TABLE II

Effect of Stirring Speed on $E_{A}$ of Intact, Vasopressin-Treated Bladders

\begin{tabular}{cc}
\hline $\begin{array}{c}\text { Stirring } \\
\text { speed }\end{array}$ & \multicolumn{1}{c}{$\mathrm{E}_{\mathrm{A}}$} \\
\hline$r p m$ & $\mathrm{kcal \cdot \text {mole } ^ { - 1 }}$ \\
$60(6)$ & $6.1 \pm 0.9(\mathrm{SE})$ \\
$128(6)$ & $7.0 \pm 0.7$ \\
$580(7)$ & $8.5 \pm 0.7$ \\
$800(8)$ & $9.3 \pm 0.8$ \\
\hline
\end{tabular}

sively as stirring speed increased; the value at $800 \mathrm{rpm}$ was significantly higher $(P<0.02)$ than that at $60 \mathrm{rpm}$.

$E_{\mathbf{\Lambda}}$ for diffusion across the epithelial layer. By determining $\mathrm{K}_{\mathrm{tran}} \mathrm{THO}$ across the intact bladder, then across the supporting layer alone, $\mathrm{K}_{\mathrm{tran}} \mathrm{THO}$ across the epithelial layer can be estimated (see Methods). In Table III, $\mathrm{K}_{\text {trans }} \mathrm{THO}$ across the epithelial layer is shown in the cold, and in paired experiments at room temperature. In the last column, $E_{\Delta}$ for the epithelial layer is shown in the absence and presence of vasopressin. Correction for the resistance of the supporting layer results in a small increase in $E_{\Delta}$ without vasopressin, and a relatively larger increase following the hormone. The difference between the two activation energies is not significant.

$E_{1}$ for diffusion across the supporting layer. In the experiments shown in Table III, $E_{\Delta}$ for the supporting layer alone was $4.3 \pm 1.1$ in the absence of vasopressin, and $5.4 \pm 0.8 \mathrm{kcal} \cdot \mathrm{mole}^{-1}$ after vasopressin. These are close to the value of $4.6 \mathrm{kcal} \cdot \mathrm{mole}^{-1}$ for diffusion of water in bulk water (8) and are consistent with the highly porous structure of the supporting layer.

\section{DISCUSSION}

Liquid water has a semicrystalline structure as the result of hydrogen bonding between neighboring water molecules $(9,10)$. Diffusion of individual water molecules is believed to require the breaking of hydrogen bonds in the water lattice; $E_{\mathbf{A}}$ for diffusion is therefore related to the number of hydrogen bonds broken $(8,11)$. In bulk water, the $E_{\Delta}$ for diffusion of $4.6 \mathrm{kcal} \cdot \mathrm{mole}^{-1}$ indicates that an average of two hydrogen bonds are

TABLE III

\begin{tabular}{|c|c|c|c|c|c|c|c|}
\hline \multirow[b]{2}{*}{ Vasopressin } & \multicolumn{3}{|c|}{$\mathrm{K}_{\text {trans }}$ cold } & \multicolumn{3}{|c|}{$\mathrm{K}_{\text {trans }}$ room temp. } & \multirow[b]{2}{*}{$\mathrm{E}_{\mathrm{A}}$ epith. } \\
\hline & Intact & Supp. & Epith. & Intact & Supp. & Epith. & \\
\hline & & $\mathrm{cm} \cdot \mathrm{sec}^{-1} \times 10^{7}$ & & & $\mathrm{~cm} \cdot \mathrm{sec}^{-1} \times 10^{7}$ & & kcal $\cdot$ mole $^{-1}$ \\
\hline Absent (10) & $436 \pm 49$ & $4734 \pm 212$ & $486 \pm 60$ & $1107 \pm 60$ & $6968 \pm 977$ & $1332 \pm 86$ & $11.7 \pm 1.4$ \\
\hline Present (7) & $2140 \pm 132$ & $5000 \pm 300$ & $4046 \pm 482$ & $4610 \pm 361$ & $8421 \pm 828$ & $10644 \pm 1688$ & $10.6 \pm 1.1$ \\
\hline
\end{tabular}

THO Diffusion across Intact Bladder, Supporting Layer, and Epithelial Layer 
broken for the movement of each water molecule (8). $\mathrm{E}_{\Delta}$ for water diffusion across many cell membranes is considerably higher than $4.6 \mathrm{kcal} \cdot \mathrm{mole}^{-1}(12)$; this can be explained either by extensive bonding of water molecules to components of narrow aqueous channels in the membrane, or by the tendency of water to assume an icelike state in the vicinity of nonpolar groups in the channel (10). In channels with large radii, on the other hand, water in the central core would assume the properties of liquid water, and $\mathrm{E}_{\Delta}$ for diffusion would be correspondingly low (note, for example, the low $E_{\Delta}$ for diffusion across the porous supporting layer, Table III). Based on this interpretation, the apparent fall in $E_{A}$ after vasopressin gave support to the pore enlargement hypothesis for hormone action.

The determination of $E_{\Delta}$ for water across epithelial cells however, depends on the accuracy with which $\mathrm{K}_{\mathrm{trans}} \mathrm{THO}$ can be measured. The resistance to diffusion offered by unstirred layers and the supporting layer is apparently not of importance in the absence of vasopressin, since our present value of $11.7 \mathrm{kcal} \cdot \mathrm{mole}^{-1}$ is not far from the value of $9.8 \mathrm{kcal} \cdot \mathrm{mole}^{-1}$ obtained in chambers where bubbling provided the only stirring (3). Following vasopressin, however, $\mathrm{K}_{\text {trans }} \mathrm{THO}$ across the epithelial cells becomes so rapid that the unstirred and supporting layers become rate limiting for diffusion, and only by correcting for these extraneous layers can the true $\mathrm{K}_{\text {trans }} \mathrm{THO}$ across the epithelial layer be determined. $E_{\mathbf{\Delta}}$ across the epithelial layer is $10.6 \mathrm{kcal} \cdot \mathrm{mole}^{-1}$, more than twice the value obtained in the earlier experiments. Even this value is probably lower than the true $E_{\mathbf{\Delta}}$ after vasopressin, since the unstirred layer effect cannot be entirely eliminated, no matter how vigorous the stirring (4). The low value for $E_{A}$ obtained in earlier experiments reflected the presence of the unstirred and the supporting layers, and gave no information about the interaction of water molecules with the epithelial cells, and notably, with the luminal membranes of these cells.

There was no significant difference between the activation energies before and after vasopressin, indicating that the extent of bonding of water molecules as they traverse the epithelial cells is uninfluenced by the hormone. The finding that $E_{\Delta}$ remains high suggests that vasopressin increases the number of small aqueous channels in the membrane rather than increasing their size. This finding is in accord with the very large increase in the diffusion rate of THO produced by the hormone (4). Since the radius of the channels would remain small, this would account for the observation that solutes with radii greater than $2.6 \mathrm{~A}$ do not penetrate the bladder more rapidly following vasopressin (13).' There-

\footnotetext{
${ }^{2}$ The amides remain an interesting exception to this rule, since the permeability of the bladder to large amides such
}

fore it becomes unnecessary to postulate that a fine diffusion barrier in series with a highly porous barrier (series barrier hypothesis) is responsible for the selectivity of the luminal membrane towards small solutes $(2,15)$.

\section{ACKNOWLEDGMENTS}

This work was supported by U. S. Public Health Service Grants AM-03858 and HD-00674, and Grant 14-01-0001-1759 from the Office of Saline Water, U. S. Department of the Interior.

\section{REFERENCES}

1. Koefoed-Johnsen, V., and H. H. Ussing. 1953. The contributions of diffusion and flow to the passage of $\mathrm{D}_{2} \mathrm{O}$ through living membranes. Acta Physiol. Scand. 28: 60.

2. Hays, R. M., and A. Leaf. 1962. Studies on the movement of water through the isolated toad bladder and its modification by vasopressin. J. Gen. Physiol. 45: 905.

3. Hays, R. M., and A. Leaf. 1962. The state of water in the isolated toad bladder in the presence and absence of vasopressin. J. Gen. Physiol. 45: 933.

4. Hays, R. M., and N. Franki. 1970. The role of water diffusion in the action of vasopressin. J. Membrane Biol. 2: 263 .

5. Hays, R. M., B. Singer, and S. Malamed. 1965. The effect of calcium withdrawal on the structure and function of the toad bladder. J. Cell Biol. 25: 195.

6. Leaf, A. 1959. The mechanism for the asymetrical distribution of endogenous lactate about the isolated toad bladder. J. Cell Comp. Physiol. 54: 103.

7. Katchalsky, A., and O. Kedem. 1962. Thermodynamics of flow processes in biological systems. Biophys. J. 2(Suppl.) : 53.

8. Wang, J. H., C. V. Robinson, and I. S. Edelman. 1953. Self-diffusion and structure of liquid water. III. Measurement of the self-diffusion of liquid water with $\mathrm{H}^{2}$, $\mathrm{H}^{3}$ and $\mathrm{O}^{18}$ as tracers. J. Amer. Chem. Soc. 75: 466.

9. Bernal, J. D., and R. H. Fowler, 1933. A theory of water and ionic solution, with particular reference to hydrogen and hydroxyl ions. J. Chem. Phys. 1: 515.

10. Frank, H. S. 1958. Covalency in the hydrogen bond and the properties of water and ice. Proc. Roy. Soc. Ser. A. Math. Phys. 247 : 481.

11. Glasstone, S., K. J. Laidler, and H. Eyring. 1941. In The Theory of Rate Processes. McGraw-Hill Book Company, Inc., New York. 1st edition. 505.

12. Dick, D. A. T. 1966. In Cell Water. Butterworths, Washington. 112.

13. Hays, R. M., S. H. Harkness, and N. Franki. 1970. The movement of urea and other small molecules across the toad bladder. In Urea and the Kidney. B. SchmidtNielson, editor. Excerpta Medica Foundation, Publishers, Amsterdam. 149.

14. Leaf, A., and R. M. Hays. 1962. Permeability of the isolated toad bladder to solutes and its modification by vasopressin. J. Gen. Physiol. 45: 921.

15. Lichtenstein, N. S., and A. Leaf. 1966. Evidence for a double series permeability barrier at the mucosal surface of the toad bladder. Ann. N. Y. Acad. Sci. 137: 556.

as dimethylformamide and nicotinamide increases after vasopressin (14). This observation remains unexplained, but may involve a specific interaction between the amide group and the membrane. 